\title{
Cooperation among SMEs in Poland on the path to their development
}

\section{Introduction}

The turbulence and permanence of the undergoing changes in the environment of contemporary enterprises, accompanied by the high dynamics of globalization processes, are creating a new reality of their functioning (Żmija, 2011), with development still unalterably being the constitutive goal of their activities on the market. As a result, enterprises undergo a constant change, transforming their functions, partial goals, tasks, and methods of organization and management due to the collapse of the hitherto prevailing paradigms of their functioning (Borowiecki and Siuta-Tokarska, 2016). The noted changes in the principles of the functioning of enterprises, information systems, and organizational structures used in them should favor flexible, more "intelligent" solutions that are applied in the models of enterprise of the future (Kubik, 2012). Quite often, the formation and implementation of these types of changes require the proper "reprogramming" and a different view of the inside and environment of an entity. The existing and newly occurring forms of cooperation of enterprises with other enterprises and other market entities (e.g., with local government units, research and development units, institutions of higher education, etc.) are to some extent a response to the occurring market challenges, among which we can indicate for (example) the growing and changing requirements of customers, shortening of product lifecycles, or growth of competition in the era of a digital economy (hence, the phenomenon of coopetition; namely, collaboration between competitors to achieve the goals set by them) (Małys, 2011). After N. Göler von Ravensburg,

\footnotetext{
* Cracow University of Economics, Department of Economics and Organization of Enterprises, e-mail siutab@uek.krakow.pl
} 
one can indicate that cooperation is an indispensable element for numerous micro-, small-, and medium-sized enterprises, which arises from the fact of the progressing processes of globalization and liberalization of economies, consequently intensifying the need for collaboration among these entities (Göler von Ravensburg, 2009).

The aim of this publication is to present the level and forms of the implementation of cooperation among SMEs in Poland, with their basic division by the type of the origin of the owner's capital (Polish and foreign capital). To achieve the goal formulated in this way, the first part of this paper indicates the significance of cooperation among enterprises on the path to their development. Then, the next part presents the findings of the author's own empirical research conducted among SMEs with Polish and foreign capital, pertaining to the undertaken forms of collaboration, size classes of the cooperating entities, and the benefits related to it.

The following questions for the research goal adopted in this way were formulated as follows:

- Do SMEs in Poland collaborate with enterprises and with other market entities, and what is the level of this collaboration (low, medium, or high)?

- With which enterprises do SMEs collaborate, taking into consideration the size classes of these entities and origin of the capital (Polish or foreign capital)?

- Which forms of cooperation are implemented most often and least often by SMEs, and are there are any differences between enterprises with Polish or foreign capital in this respect?

With the research questions defined in this way, the following three hypotheses were adopted:

H1: Enterprises of the SME sector in Poland cooperate both with enterprises and other entities on the market, but the share of SMEs cooperating with other enterprises is greater than with other market entities.

H2: When differentiating SMEs by their size classes, the percentage of cooperating enterprises increases with the growth of the size class of the entity (the smallest - among micro-enterprises, and the biggest - among medium-sized enterprises).

H3: Among the enterprises of the SME sector in Poland, cooperative firms of their collaboration prevail, whereas considering the differentiation of enterprises by the origin of their capital the author made - SMEs with foreign capital use concentrated forms of cooperation to a greater extent than SMEs with Polish capital. 


\section{Cooperation among enterprises as factor of their development}

Development being a manifestation of all forms of life is the object of interest of, among others, philosophy as well as the natural and social sciences (Siuta-Tokarska, 2015).

In general, development is treated as a long-term process of purposeful changes in which successive stages of transformations can be distinguished (Brózda, 2002).

According to W. Gabrusewicz, the development of enterprises is understood as an evolutionary and long-term process of purposeful quantitative and qualitative changes leading from simpler, relatively not very diverse forms or states to more-complex and more-diverse forms or states significantly transforming the inner structure of an enterprise and its operating methods (Siuta-Tokarska, 2015). It is assessed and adopted as a justified assertion that, just like the changeability of matter, is the driver of any development, the essence of the development of an enterprise are changes made in it, and the development of an enterprise is mostly affected by those changes that identify the occurring problems and show the ways and possibilities of solving them (Siuta-Tokarska, 2015). Moreover, it is assumed that, in the assessment of the development of social and economic phenomena, one should apply the category of progress understood as changes that aim to enrich the entity and consist of passing from the lower to higher stages of the entity's development, and the enriching refers to the individual components and relationships among them. While discussing the development of an individual economic entity, one must bear in mind that, in spite of a general similarity in the progression of the process of these entities' development, their development differs in terms of the type, subject, and scope of the changes (Siuta-Tokarska, 2015), which is particularly visible with regard to SMEs (among which, we can distinguish micro-, small-, and medium-sized business entities).

The dynamics and structure of the developmental processes are primarily determined by the factors of development; the basic division of which grasps the external and internal factors of enterprise development. All of the factors may have a stimulating or destimulating influence on the development of the enterprises; therefore, they may positively influence its development or be its restraint, and their effects may cancel each other out in some cases (Siuta-Tokarska, 2015). As a result, the factors of development cause or contribute to the occurrence of a change in an enterprise, a consequence of which new challenges for an enterprise occur, which may then change the character, dynamics, and mutual penetration of the processes undergoing in it (Walas-Trębacz, 2004). 
Thus, enterprises in which the strive for (Walas-Trębacz, 2004):

- a fast reaction to changes undergoing on the economic market;

- adaptation to multidirectional changes in the environment;

- the manufacturing of products meeting the expectations of the recipients and/or the creation of needs for a specific product;

- the proper forecasting of changes in the environment and identification of those factors whose impact will be decisive (determinants) for the competitive potential of the entity and coping with the occurring power of competition (advantage) and, as a consequence, achieving an adequate position on the market;

- the creation of new ideas as well as the creation of new values;

- the development of an individual

is visible, more and more often use opportunities related to the implementation of ventures with support from an external partner in the form of cooperation (Rundo and Ziółkowska, 2013; Karwacka, 2016). As M. Strzyżewska points out, studies on alliance capitalism and new forms of the organization of enterprises confirm that, over the last few decades, cooperation among Polish enterprises and among enterprises from different countries has created a powerful leveraging of the development of enterprises and their internationalization (Strzyżewska, 2001). The area of research within this scope also concerns SMEs, and the issue of cooperation is regarded as important and significant for their development (Adamik, 2012; Borowiecki and Siuta-Tokarska, 2008).

The notion of the cooperation among enterprises can be understood as a type of collaboration characterized by the coordination of activities within the established relationships, with identical or complementary goals undertaken by entities in order to achieve the results desired by all of the interested parties (Małys, 2011). The occurrence of the categorization of goals (interests) of the cooperating parties is indicated into the following (Małys, 2011):

- individual goals that motivate the entrance into relationships based on cooperation;

- strategic goals that the parties try to defend (e.g., arising from other relationships within the cooperation;

- common goals arising from the commonness of the goals of all parties to the collaboration process.

Among the numerous motives of undertaking cooperation by entrepreneurs as indicated in the literature of the subject, the following are particularly worth paying attention to (Ratajczak-Mrozek, 2011; Barczak, 2016):

- the better use of market opportunities;

- increasing the bargaining power towards suppliers and recipients and strengthening the position in comparison with the competitors; 
- the possibility to raise funds and increased speed of the implementation of investment ventures;

- the growth of added value;

- an increase in the access to information;

- achieving access to complementary resources of partners (raw materials and materials, products and technical solutions, human capital) as well as their knowledge and experience with regards to the organization and management or research and development;

- the implementation of the process of learning "within created and developed interorganizational bonds";

- an opportunity to improve employee qualifications by using good practices of cooperation;

- the access to customers and business partners;

- extending the range and improvement of the quality of the products;

- the facilitation of the distribution of products, developing a distribution network;

- reducing the risk of activity;

- the possibility to reduce the costs of activity;

- the possibility to achieve economies of scale;

- the possibility of the faster internationalization of the enterprise activity.

The relationships that will be established based on cooperation should contribute to an increase in the effectiveness of an organization (Olesiński, 2010) as well as to an increase in its developmental potential and the implementation of development itself as a consequence. Thus, the subject matter of cooperation among organizations concerns various research areas with a broad spectrum of significance for their development, as the following (for example) (The Oxford Handbook..., 2008):

- organizational issues, including cooperation between enterprises by industries, size classes, the time of an enterprise's activity ("the age of the enterprise"), the stage of development, the country of origin, the dissimilarity of organizational cultures, the number of business partners, the consequences concerning the spatial arrangement of an organization in the established regional clusters or industrial areas, and the diversification of activities and types of cooperation between partners;

- the issues of connections and bonds linking the studied entities, such as interactional and non-interactional relationships, the way of formulating cooperation, prevailing ways of managing cooperation, the relationships and the significance of power in the cooperation process; 
- the issues of the dimensions and attributes of the context of the implementation of cooperation, such as the influence of the cultural and institutional environment on cooperation, access to material and immaterial resources, access to explicit and tacit knowledge, intensity and frequency of the flow of resources and information among the entities, issue of the "closeness" of the relationships, and impact of other factors on the collaboration; e.g., the geographical location, availability of infrastructure, or influence of external entities;

- issues of a constitutive character: sources of cooperation and trajectory of related processes (phases of the cooperation process, evolution of coordination structures in the context of time, reasons for ending cooperation).

An analysis of the literature of the subject also inclines to the reflection that making a decision about cooperating with another entity is preceded by an adequate entrepreneur's calculation of both the opportunities and threats that may be related to it. Therefore, the factors that determine cooperation are multidimensional and varied (Tab. 1).

Table 1

Factors determining cooperation among enterprises

\begin{tabular}{|l|l|l|}
\hline \multicolumn{1}{|c|}{ Criterion } & \multicolumn{1}{|c|}{ Types of factors } & Authors \\
\hline $\begin{array}{l}\text { Form of cooperation } \\
\text { (traditional or con- } \\
\text { temporary) }\end{array}$ & $\begin{array}{l}\text { Peripheral or native areas, lack or existence of } \\
\text { competition between partners, lesser or greater } \\
\text { significance of capital control, local or global } \\
\text { character of cooperation, types of key resources, } \\
\text { single agreements or networks of agreement, } \\
\text { regionalization or its lack, forced agreements } \\
\text { (e.g., related to legislation) or voluntary ones. }\end{array}$ & A. Sulejewicz \\
\hline $\begin{array}{l}\text { External and internal } \\
\text { forces }\end{array}$ & $\begin{array}{l}\text { Globalization of markets, fast dissemination } \\
\text { and shortening of lifecycle of new technologies } \\
\text { and products, development of opportunities to } \\
\text { achieve economies of scale, growing turbulence } \\
\text { and uncertainty in economy, liquidation } \\
\text { of barriers in international trade, scope of } \\
\text { activities and experience, sense of inadequacy } \\
\text { of resources or qualities of enterprise } \\
\text { competitiveness. }\end{array}$ & $\begin{array}{l}\text { D. Faulkner, } \\
\text { Cowman }\end{array}$ \\
\hline
\end{tabular}




\begin{tabular}{|c|c|c|}
\hline $\begin{array}{l}\text { Types of effects } \\
\text { possible to be } \\
\text { achieved }\end{array}$ & $\begin{array}{l}\text { Reduction of uncertainty, increasing flexibility, } \\
\text { possibility to acquire new developmental } \\
\text { abilities, possibility to access deficit resources } \\
\text { and skills, acquiring information, possibility } \\
\text { to operate faster. }\end{array}$ & $\begin{array}{l}\text { J. Child, } \\
\text { D. Faulkner }\end{array}$ \\
\hline $\begin{array}{l}\text { Function of } \\
\text { implemented } \\
\text { cooperation }\end{array}$ & $\begin{array}{l}\text { Stabilizing, specializing, directing, integrating, } \\
\text { inspiring. }\end{array}$ & M.E. Porter \\
\hline $\begin{array}{l}\text { Organizational } \\
\text { factors }\end{array}$ & $\begin{array}{l}\text { Attributes of enterprise such as age and size of } \\
\text { enterprise, business strategies, organizational } \\
\text { structure and management system, specific } \\
\text { resources of enterprise, dynamic ability. }\end{array}$ & $\begin{array}{l}\text { B. Siuta- } \\
\text {-Tokarska }\end{array}$ \\
\hline $\begin{array}{l}\text { Personality and } \\
\text { cultural factors }\end{array}$ & $\begin{array}{l}\text { Individual factors concerning entrepreneur } \\
\text { (e.g., traits of character, taking risk, individual } \\
\text { competences, ability to establish contacts), } \\
\text { cultural traditions concerning (e.g., a given } \\
\text { region or country). }\end{array}$ & $\begin{array}{l}\text { S. Slatter, } \\
\text { D. Lovett }\end{array}$ \\
\hline Labor resources & $\begin{array}{l}\text { Skills of employees and managers, resource } \\
\text { management, and entrepreneurship of the staff. }\end{array}$ & W. Danielak \\
\hline Social factors & $\begin{array}{l}\text { Level of mutual trust, two-sidedness, speed, and } \\
\text { peaceableness of information flow. }\end{array}$ & W. Czakon \\
\hline $\begin{array}{l}\text { "Proximity" } \\
\text { dimension of } \\
\text { cooperating entities }\end{array}$ & $\begin{array}{l}\text { Social (relational), cognitive (technological), } \\
\text { organizational, institutional (cultural) proximity. }\end{array}$ & J. Bryant \\
\hline
\end{tabular}

Source: own study based on: (Bryant, 2003; Child and Faulkner, 2005; Czakon, 2007; Danielak, 1999; Faulkner and Bowman, 1999; Porter, 2001; Siuta-Tokarska, 2015; Slatter and Lovett, 2001; Sulejewicz, 1997).

As was indicated in this section of the article, the issue of the cooperation among enterprises is an important and characteristic element that determines their development. Therefore, this research area requires particular attention, and the empirical research findings in this respect are the significant part of this area.

\section{Criteria and selection of research objects}

To assess the level of cooperation among enterprises, entities being non-financial SMEs were examined, among which were distinguished micro-, small-, and medium-sized enterprises. Within the research, the enterprises were separated 
into enterprises with Polish capital (which should be understood as enterprises with Polish private ownership and mixed ownership, with the dominance of the capital of entities of Polish private ownership controlled by Polish private entities, as well as all the entities that are included in the sector of non-financial enterprises and were not classified as entities with foreign capital) and enterprises with foreign capital (namely, private entities with foreign capital and of mixed ownership with the dominance of the capital of foreign entities controlled by non-residents, which are included in the sector of non-financial enterprises).

Based on the sections of Polish Classification of Activity (PKD) 2007, the following are distinguished: industrial, construction, transport, commercial, and service enterprises.

In the process of selecting a research sample upon the stratification of the studied enterprises into specific groups, a stratified random sampling was chosen. In the work on the research into cooperation among enterprises, the method of triangulation of research techniques was used: structured interviews in the form of mail surveys; direct interviews conducted via the Internet (the so-called CAWI); and direct computer-assisted phone interviews (the so-called CATI). In total, from January to July 2013 (considering the research period of 2007-2012, which is the period of the global economic crisis ${ }^{1}, 501$ enterprises were examined, including 251 with Polish

\footnotetext{
${ }^{1}$ During the years 2013-2016, the activities of SMEs were influenced by the general improvement of the economic situation in Poland as compared to the aforementioned research period. This can be indicated, among others, by the results achieved by all enterprises during the years 2013-2015, including the activities of the SME sector (Działalność..., 2014; Działalność..., 2015; Działalność..., 2016). It is worth emphasizing that the findings of the research of other authors concerning the cooperation among enterprises and conduced after 2013 confirm an increasing share of SMEs in Poland cooperating with other enterprises; moreover, they indicate cooperation of some of these enterprises with research and development units and institutions of higher education, which was also the subject of the research of the author of this publication. What results from the research conducted among 148 SMEs from Łódz and Masovian Voivodeships from May to July 2014 is that $68.3 \%$ of the entities cooperated with other enterprises in the same industry (including $68.3 \%$ of micro-, $65.9 \%$ of small-, and $73.7 \%$ of medium-sized enterprises), and $34.5 \%$ cooperated with research and development units and institutions of higher education (including 28\% of micro-, 34.1\% of small-, and $63.2 \%$ of medium-sized enterprises). The dominating percentage of entities was indicated in respect to cooperation with distributors/recipients $(90.3 \%)$, with suppliers $(86.2 \%$ of the studied SMEs), but it was also significant with regard to cooperation with producer groups, holdings, or capital groups (36.6\%). On the other hand, a low percentage of enterprises was indicated with regard to cooperation with business environment institutions (15.9\%), local government units (15.2\%), non-profit organizations (7.6\%), and clusters (4.1\%) (Lisowska, 2015). Also, based on the research considering SMEs characterized by the growth potential, an increase in the share of entities cooperating with other entities was proven. What results from the research presented in the "Polish Startups" report is that the share of SME startups in which cooperation with the scientific and research sector was indicated increased from 25\% in 2015 to $42 \%$ in 2016 (Polskie startupy..., 2015; Polskie startupy..., 2016). In the European Commission publication, an increase in the share of innovative SMEs in Poland cooperating with other entities in their total number is pointed out, from $4.2 \%$ in 2013 to $6.8 \%$ in 2015 (Innovation..., 2014; European..., 2016).
} 
capital and 250 with foreign capital from three regions of Poland differing in terms of socio-economic development; namely, the central, southern, and eastern regions. Among the studied enterprises, considering the size classes of the entities, $43 \%$ were micro-enterprises, $37 \%$ were small enterprises and $20 \%$ were medium-sized enterprises, and taking into consideration their types of activity, 20\% were industrial enterprises, $15 \%$ were construction enterprises, $8 \%$ were transport enterprises, $38 \%$ were commercial enterprises, and 19\% were service enterprises.

In the paper, in order to compare enterprises distinguished in terms of capital, the structure similarity measure was used, which is described with the following formula:

$$
P S=\sum_{i=1}^{n} \min \left(p i_{1}, p i_{2}\right)
$$

where ${ }^{2}$ :

$i$ - number of structure component,

$n$ - number of structure components,

$p i_{1}$ - share of the $i$-nth component in the first structure,

$p i_{1}$ - share of the $i$-nth component in the second structure,

min - minimum value of the structure component.

The use of the taxonomic method will enable to show similarities and differences in respect of the implemented cooperation among the studied enterprises with Polish and foreign capital.

\section{Findings of author's own research into cooperation among SMEs in Poland}

Considering the specificity of the SME sector, we can indicate that cooperation within the enterprises of this sector and with other entities on the market should be an integral part of this development.

${ }^{2}$ With regard to the studied and analysed similarity of the structures of SMEs with Polish and foreign capital, considering their size classes and types of activities, the following measures of their similarity were adopted:

$<0.8 ; 1.0>-$ two structures are similar to a great extent; and for the value of "1.0", full similarity of the studied structures is indicated,

$<0.6 ; 0.8)$ - two structures are similar to a moderate extent,

$<0.4 ; 0.6)-$ two structures are similar to a low extent,

$<0.2 ; 0.4)$ - two structures are similar to a very low extent,

$<0 ; 0.2)$ - two structures are different; and for the value of " 0 ", full dissimilarity of the studied structures is indicated. 
As K. Poznańska shows, under the conditions of globalization, one of the concepts that provides the opportunity to achieve permanent competitive advantages is the stimulation of various forms of cooperation among enterprises (Poznańska, 2010), and cooperation among enterprises and institutions of the business environment also influences the growth of their competitiveness ${ }^{3}$. As M. Romanowska observes, the ideal is an enterprise in which collaboration and not competition is searched for, in which numerous agreements with suppliers and purchasers as well as alliances with competitors are concluded for the needs of building a full offer (Romanowska, 2001).

The findings of the research into the cooperation among small- and medium-sized enterprises in Poland show that a special place in these enterprises is taken by cooperation within the supply chain (suppliers - subcontractors - customers) and to a lesser extent with other entities within horizontal connections (competitors, industry organizations, local governments, and others) (Małys, 2011). As a result, the links of the enterprises have a more vertical than horizontal character (Górzyński, et al., 2006). When comparing the intensity (the number of entities with which the entity cooperates), conditions (formal and informal cooperation), and level of the implemented forms of cooperation (from simple to complex) of SMEs in Poland with enterprises of this sector in Western European countries, a substantial insufficiency in the case of Polish entities of this type becomes evident (Olesiński, 2010; Siuta-Tokarska, 2015).

The research into cooperation among SMEs with Polish and foreign capital with other entities (apart from enterprises) such as research units, institutions of higher education, local government units, and others showed a relatively low share of SMEs implementing such cooperation.

Considering the size classes of the enterprises (Fig. 1), one can notice an insignificant difference between the enterprises with Polish and foreign capital, whereas the similarity of their structures is high.

Among the SMEs with Polish capital, the biggest share of cooperating enterprises concerned medium-sized enterprises (23.9\%), then micro-enterprises (17.3\%), and the smallest was noted among small enterprises (14\%). For enterprises with foreign capital, the biggest share was noted among micro-enterprises (29\%) and was similar among small and medium-sized enterprises (about 24\%).

Some differences between the SMEs with Polish and foreign capital are visible depending on the type of the activity of the enterprises (Fig. 2).

\footnotetext{
${ }^{3} \mathrm{E}$. Wojnicka's study proved that, among the specific group of enterprises conducting industrial activities, there was a positive influence of the greater intensity of agreements for innovations, causing a greater share of innovative activity revenues in the total revenues of this group. Moreover, an indirect impact of cooperation with institutions of higher education and knowledge-intensive business support services on high profitability and an increase in the market share of these enterprises was proven (Wojnicka, 2004).
} 


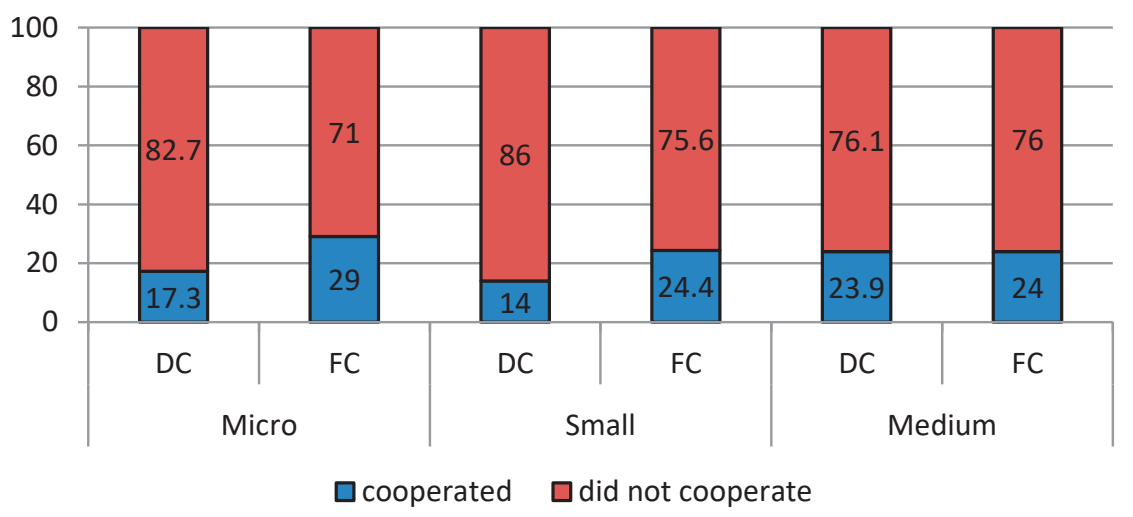

\begin{tabular}{|c|c|c|c|}
\hline \multirow{2}{*}{ PS } & Micro-enterprises & Small enterprises & Medium-sized enterprises \\
\cline { 2 - 4 } & 0.88 & 0.90 & 0.99 \\
\hline
\end{tabular}

Notations: DC - enterprises with domestic (Polish) capital; FC - enterprises with foreign capital

Figure 1. Structure of SMEs with Polish and foreign capital in Poland cooperating with other entities on economic market by their size classes and similarity of their structures (PS)

Source: own study

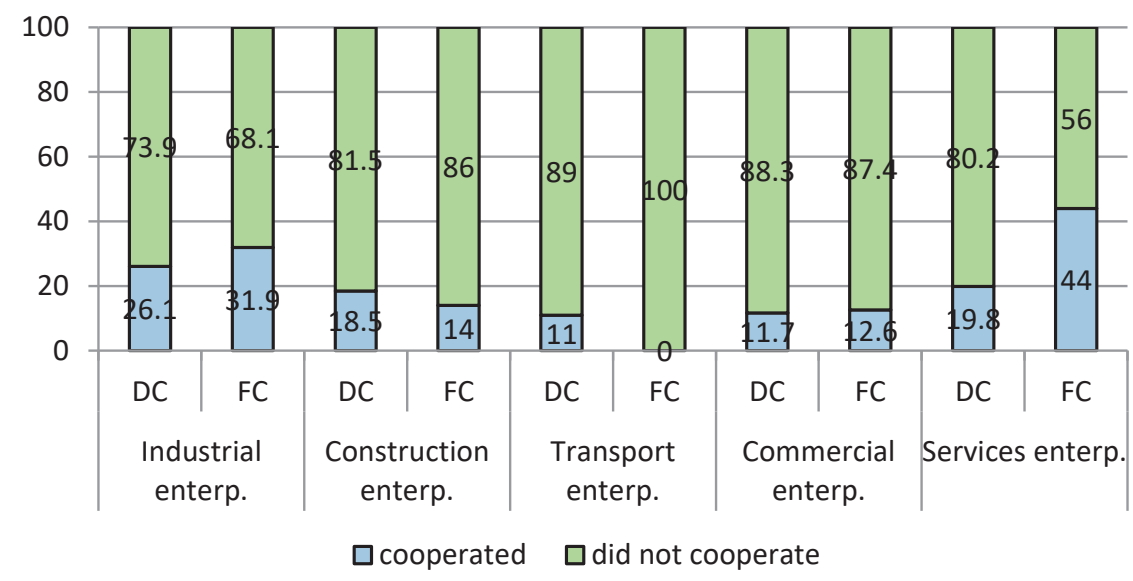

\begin{tabular}{|c|c|c|c|c|c|}
\hline \multirow{2}{*}{ PS } & Industrial & Construction & Transport & Commercial & Service \\
\cline { 2 - 6 } & 0.94 & 0.96 & 0.89 & 0.99 & 0.76 \\
\hline
\end{tabular}

Notations: DC - enterprises with domestic (Polish) capital; FC - enterprises with foreign capital

Figure 2. Structure of SMEs with Polish and foreign capital in Poland cooperating with other entities on economic market by types of their activity and similarity of their structures (PS)

Source: own study 
Among the enterprises with Polish capital, the biggest share of enterprises cooperating with other entities was noted among industrial enterprises $(26.1 \%)$, then service enterprises (19.8\%), construction enterprises (18.5\%), and the lowest among transport and commercial ones (about 11\%). In enterprises with foreign capital, the biggest share was observed among service enterprises (44\%), then industrial ones (31.9\%), and this was considerably smaller among construction (14\%) and commercial enterprises (12.6\%), whereas no cooperation was proven among transport firms. To generalize the obtained results, one can notice that the similarity of the studied structures of enterprises with Polish and foreign capital by their types of activity is high (PS $\geq 0.8$ ), with the exclusion of service firms (PS $<0.8$ ).

In the research part concerning cooperation among the SMEs with Polish capital and with foreign capital with enterprises, it was proven that the majority of the studied enterprises (more than 67\%) implemented cooperation on the economic market, whereas in the smaller part of them, the lack of such cooperation was indicated (Fig. 3) ${ }^{4}$.

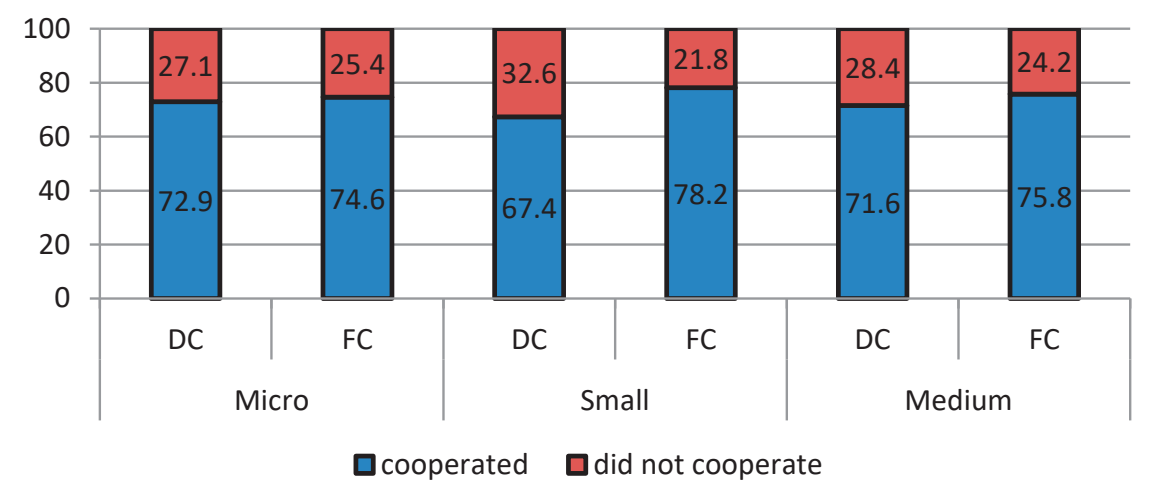

\begin{tabular}{|c|c|c|c|}
\hline \multirow{2}{*}{ PS } & Micro-enterprises & Small enterprises & $\begin{array}{c}\text { Medium-sized enter- } \\
\text { prises }\end{array}$ \\
\cline { 2 - 4 } & 0.98 & 0.89 & 0.96 \\
\hline
\end{tabular}

Notations: DC - enterprises with domestic (Polish) capital; FC - enterprises with foreign capital

Figure 3. Structure of SMEs with Polish and foreign capital in Poland cooperating with other enterprises by their size classes and similarity of their structures (PS)

Source: own study.

As a result, the similarity of the structures of enterprises with Polish and foreign capital was high; the highest was for micro-enterprises (PS $=0.98)$, then for medium-sized (PS =0.96), and the lowest was for small enterprises (PS = 0.89).

\footnotetext{
${ }^{4}$ This concerns contractual, non-contractual, and other cooperative forms.
} 
In the paper, a research period of a few years was adopted - six years altogether, which undoubtedly was of great significance for the obtained research findings.

Taking into consideration the individual types of activities of SMEs (Fig. 4), the similarity of the structures of enterprises with Polish and foreign capital was high for commercial enterprises (PS $=0.99)$, service (PS $=0.98)$, construction (PS $=0.97$ ), and transport enterprises $(\mathrm{PS}=0.80)$; it was medium for industrial enterprises (PS $=0.77$ ). As for industrial enterprises with Polish capital, the highest percentage of enterprises that did not cooperate with other enterprises was indicated when compared to the other four types of activity, opposite to that in the case of enterprises with foreign capital.

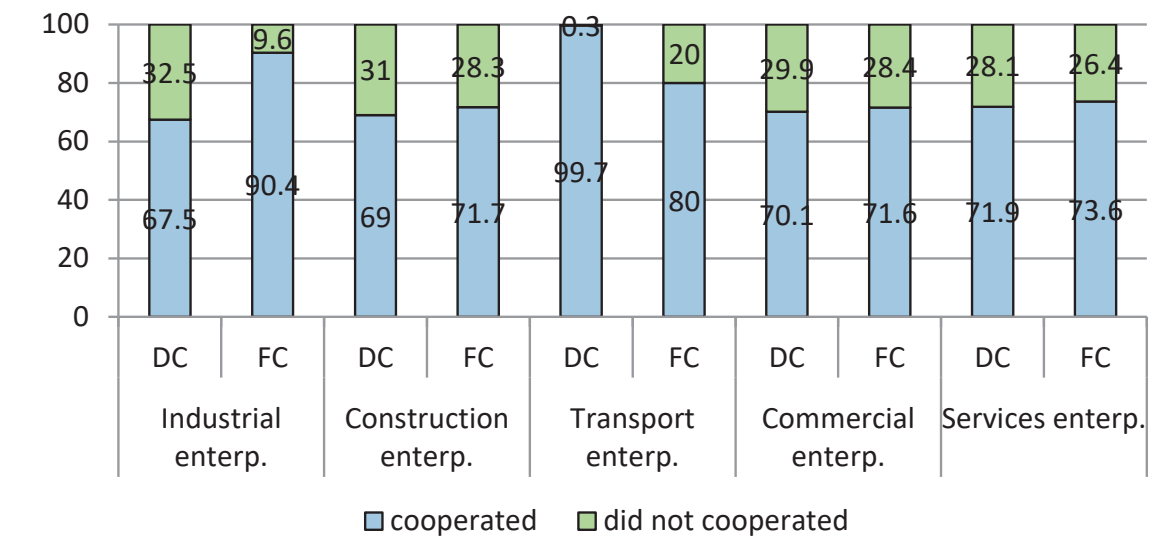

\begin{tabular}{|c|c|c|c|c|c|}
\hline \multirow{2}{*}{ PS } & Industrial & Construction & Transport & Commercial & Service \\
\cline { 2 - 6 } & 0.77 & 0.97 & 0.80 & 0.99 & 0.98 \\
\hline
\end{tabular}

Notations: DC - enterprises with domestic (Polish) capital; FC - enterprises with foreign capital

Figure 4. Structure of SMEs with Polish and foreign capital in Poland cooperating with other enterprises by types of their activities and similarity of their structures (PS)

Source: own study

Within the author's own research, the level of cooperation among SMEs ${ }^{5}$ with Polish and foreign capital was also assessed, considering the size classes of the enterprises with which the studied SMEs cooperated (Fig. 5).

5 The notion "level of cooperation" should be understood here as the share of cooperating enterprises among the total number of enterprises. Cooperation with enterprises is understood both as cooperation among enterprises inside the SME sector (e.g., cooperation of some micro-enterprises with other micro-enterprises) as well as with small and medium-sized enterprises; also, with enterprises from the outside the SME sector, it concerns the large enterprise sector. 


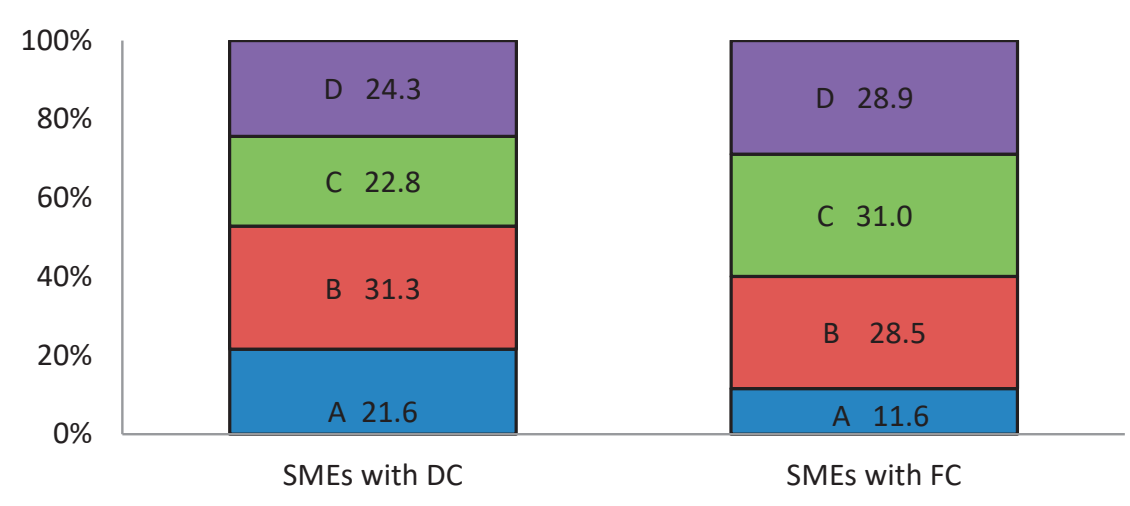

$$
\text { PS }=0.87
$$

Notations: A - micro-enterprises; B - small enterprises; C - medium-sized enterprises; D - large enterprises; DC - domestic capital; FC - foreign capital.

Figure 5. Structure of SMEs with Polish and foreign capital in Poland cooperating with enterprises by their size classes and similarity of their structures (PS)

Source: own study

Both among SMEs with Polish and foreign capital, the dominating share was depicted for the SMEs cooperating with other enterprises of the SME sector (about $76 \%$ of the enterprises with Polish capital and more than $71 \%$ with foreign capital), whereas enterprises cooperating with large business entities had a minority share (more than $24 \%$ and about $29 \%$, respectively).

The differences between the studied enterprises with Polish and foreign capital in respect to cooperation inside the SME sector are related to the following:

- minority share of enterprises with foreign capital with regard to cooperation with enterprises in lower classes of their size, that is the lowest share for micro-enterprises, higher for small enterprises, and highest for medium-sized enterprises;

- the highest share of the enterprises with Polish capital with regard to cooperation with small enterprises, and smaller but similar shares with regard to cooperation with medium-sized enterprises and micro-enterprises.

Considering the type of capital (Polish and foreign enterprises) with which the studied SMEs cooperated, one may notice the following (Fig. 6):

- SMEs with Polish capital cooperated in particular with Polish enterprises $(53.7 \%)$, then with both Polish and foreign ones (40.4\%), and the smallest number of them cooperated only with enterprises with foreign capital (5.9\%); 
- SMEs with foreign capital cooperated mostly with enterprises with Polish and foreign capital (59.7\%), then a smaller number of them cooperated only with enterprises with Polish capital (26.3\%), and the smallest number (14\%) only with entities with foreign capital.

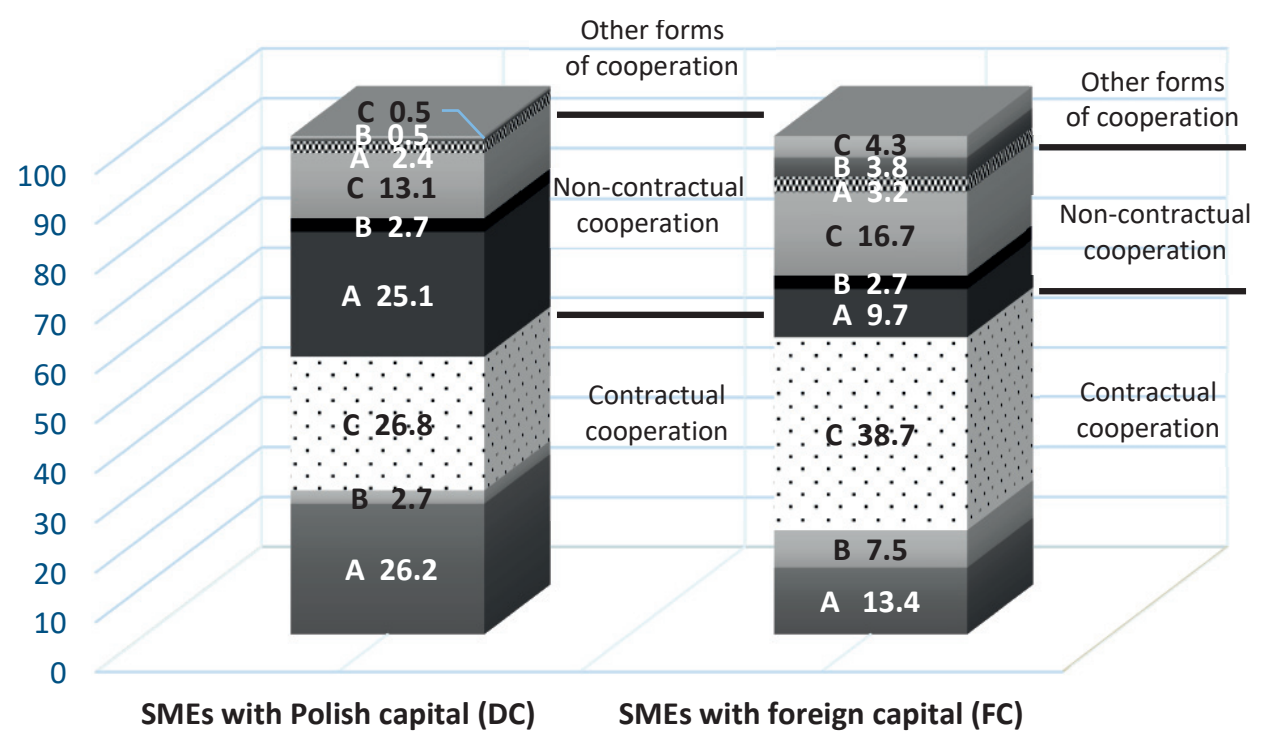

$\mathrm{PS}=0.73$

Notations: A - cooperation among studied SMEs with enterprises with Polish capital; B - cooperation among studied SMEs with enterprises with foreign capital; C - cooperation among studied SMEs with enterprises with Polish capital and with enterprises with foreign capital; DC - domestic capital; FC - foreign capital.

Figure 6. Structure of SMEs with Polish and foreign capital by type of implemented cooperation and type of capital of cooperating enterprises

Source: own study

Within the research conducted by the author, among the SMEs with Polish and foreign capital, the following forms of their cooperation with other enterprises were proven:

- contractual cooperation - as the basic form (most often indicated in the enterprises);

- non-contractual cooperation;

- other forms of cooperation (including the so-called loose and dense concentration forms), which were used by the studied enterprises to the least extent. 
The similarity of the structures of SMEs with Polish and foreign capital can be defined as moderate (PS $=0.73$ ). The fundamental differences concern the use of other forms of cooperation because, for SMEs with Polish capital, this form of cooperation was used by only $3.4 \%$ of the studied enterprises, whereas for SMEs with foreign capital, the share was $\mathbf{1 1 . 3 \%}$, as well as non-contractual cooperation: among SMEs with Polish capital, this form of cooperation concerned $40.9 \%$ of the studied enterprises and $29.1 \%$ of entities with foreign capital.

It is also worth paying attention to the benefits related to this cooperation as indicated by entrepreneurs. To make an appropriate division of the benefits the studied enterprises could achieve from the undertaken cooperation with other enterprises, we can distinguish the following:

- qualitative benefits:

- improvement in the quality of products/services,

- access to specialist knowledge,

- possibility to implement innovative solutions,

- growth of the prestige of the enterprise,

- establishing business contacts;

- quantitative benefits:

- gaining new customers,

- winning new markets,

- greater export opportunities,

- reduction of business costs;

quantitative and qualitative benefits:

- growth of competitiveness of the enterprise,

- other benefits.

Among the studied SMEs, the following were indicated most often: benefits related to winning new customers (23.8\% of SMEs with Polish capital and $23.5 \%$ of SMEs with foreign capital), and then to the growth of competitiveness (13.2\% and $14.5 \%$, respectively), as well as the growth of prestige (11.1\% and $15 \%)$, whereas least frequently, the access to specialist knowledge was indicated ( $4 \%$ and $3.3 \%$ ), the possibility to implement innovative solutions (10\% and 3.8\%), and other benefits (3\% and $2.5 \%$ ). The similarity of the structures of the studied SMEs with Polish and foreign capital was high (PS = 0.92).

\section{Conclusions and recommendations}

Based on the analysis of the literature of the subject concerning the problem of cooperation among enterprises, one can clearly indicate that such cooperation is an important element of the growth of their competitiveness in the short 
term, whereas in the long run, it is an integral factor of their development. The results of the research into SMEs in Poland as compared to Western European countries prove that these enterprises have a considerable potential that is used insufficiently. This can be proven (among others) by the findings of the author's own research with the capital differentiation of these enterprises. Among the SMEs with foreign capital in Poland as compared to those with Polish capital, a substantially higher percentage of the entities implementing cooperation with other market entities was observed, both by their size classes and their types of activities (construction and transport enterprises were the exceptions), just like in respect to the cooperation with other enterprises (transport enterprises were the exception). Some differences among the studied SMEs with Polish and foreign capital were manifested in respect to the different forms of cooperation used by them (the enterprises with foreign capital more willingly implement other forms of cooperation with enterprises, including concentration forms of cooperation loose and dense ones), whereas the differences concerning the size classes of the enterprises with which they cooperated were insignificant; thus, the similarity of their structures was high.

In addition to the presented empirical and cognitive conclusions, the implementation of the author's own research also enabled the verification of the adopted research hypotheses (Tab. 2).

Table 2

Collation of results of verification of research hypotheses

\begin{tabular}{|c|l|c|}
\hline No. & \multicolumn{1}{|c|}{ Content of adopted hypothesis } & $\begin{array}{c}\text { Result of } \\
\text { verification }\end{array}$ \\
\hline H.1 & $\begin{array}{l}\text { SMEs in Poland cooperate with both enterprises and other entities } \\
\text { on the market, and the share of SMEs cooperating with enterprises } \\
\text { is greater than with other market entities. }\end{array}$ & + \\
\hline H.2 & $\begin{array}{l}\text { Differentiation of SMEs by their size classes, the percentage of } \\
\text { cooperating enterprises increases with the growth of the size class } \\
\text { of the entity (the smallest - among micro-enterprises; the largest - } \\
\text { among medium-sized enterprises). }\end{array}$ & + \\
\hline H.3 & $\begin{array}{l}\text { Among SMEs in Poland, cooperative forms of their cooperation } \\
\text { prevail, whereas with the differentiation of enterprises by the ori- } \\
\text { gin of their capital - SMEs with foreign capital use concentration } \\
\text { forms of cooperation to a greater extent than SMEs with Polish } \\
\text { capital. }\end{array}$ & + \\
\hline
\end{tabular}

Explanation: the "+" sign indicates that the hypothesis was proven; 0 - no grounds for the acceptance nor the rejection of the hypothesis; the "-" sign indicates that the hypothesis was verified negatively (the hypothesis was not confirmed). 
To sum up the above conclusions arising from the conducted literature analysis and the author's own research, one can claim that the cooperation among SMEs in Poland is implemented, both with enterprises inside their sector and with large enterprises; however, the extent of this cooperation is insufficient. Polish enterprises basically use the so-called concentration forms to a lesser extent as compared to foreign enterprises, whereas the basic form of the cooperation implemented by them is cooperation (contractual and non-contractual). What is visible is the potential of these enterprises and the possibilities to increase their activities in the area of cooperation with other enterprises and other market entities, such as local government units, research and development units, or institutions of higher education in order to improve their competitiveness and implement their development.

\section{References}

[1] Adamik, A. (ed.) (2012) Współpraca małych i średnich przedsiębiorstw w regionie. Budowanie konkurencyjności firm i regionu, Warszawa: Difin.

[2] Barczak, B. (2016) 'Korzyści ze współpracy podmiotów w ramach sieci organizacyjnych', in: Czubasiewicz, H., Grajewski, P. and Waśniewski, J. (eds.) Perspektywy spojrzenia na czynniki sukcesu organizacji XXI wieku, Sopot: Wydział Zarządzania Uniwersytetu Gdańskiego.

[3] Borowiecki, R. and Siuta-Tokarska, B. (2016) 'Konkurencyjność przedsiębiorstw sektora MŚP w świetle samooceny ich właścicieli i menedżerów’, Przeglad Organizacji, No. 10.

[4] Borowiecki, R. and Siuta-Tokarska, B. (2008) Problemy funkcjonowania i rozwoju małych i średnich przedsiębiorstw w Polsce. Synteza badań i kierunki działania, Warszawa: Difin.

[5] Brózda, J. (2002) 'Konceptualizacja kategorii rozwoju', in Białasiewicz, M. (ed.) Rozwój przedsiębiorstw: modele, czynniki, strategie, Rozprawy i Studia, vol. 414, Szczecin: Uniwersytet Szczeciński.

[6] Bryant, J. (2003) The Six Dilemmas of Collaboration. Interorganisational Relationships as Drama, West Sussex: John Wiley \& Sons.

[7] Child, J. and Faulkner, D. (2005) Cooperative Strategy. Managing Alliances, Networks and Joint Ventures, Oxford: Oxford University Press.

[8] Czakon, W. (2007) 'Sieci międzyorganizacyjne a niepewność w zarządzaniu przedsiębiorstwem', in Kozakiewicz, K. (ed.), Zmiany w systemach zarządzania polskich przedsiębiorstw, Poznań: Wydawnictwo AE w Poznaniu.

[9] Danielak, W. (1999) 'Problemy rozwoju małych i średnich przedsiębiorstw', in Nowoczesne zarządzanie przedsiębiorstwem, Zielona Góra: Oficyna Wydawnicza Uniwersytetu Zielonogórskiego. 
[10] Działalność przedsiębiorstw niefinansowych w 2013 r. (2014), Warszawa: Central Statistical Office.

[11] Działalność przedsiębiorstw niefinansowych w 2014 r. (2015), Warszawa: Central Statistical Office.

[12] Działalność przedsiębiorstw niefinansowych w 2015 r. (2016), Warszawa: Central Statistical Office.

[13] European Innovation Scoreboard 2016 (2016), European Commission, Belgium.

[14] Faulkner, D. and Bowman, C. (1999) Strategie konkurencji, Warszawa: Felberg SJA.

[15] Göler von Ravensburg, N. (2009) Enterprises future lies in cooperation - Entrepreneur Cooperatives in Africa, Geneva: International Labour Organization.

[16] Górzyński, M., Pander, W. and Koć, P. (2006) Tworzenie związków kooperacyjnych między MSP oraz MSP i instytucjami otoczenia biznesu, Warszawa: Polska Agencja Rozwoju Przedsiębiorczości.

[17] Innovation Union Scoreboard 2014 (2014), European Commission, Belgium.

[18] Karwacka, M. (2016) Siła współpracy. Relacje przedsiębiorstw z organizacjami pozarządowymi w kontekście społecznej odpowiedzialności biznesu, Kraków: Zakład Wydawniczy „Nomos”.

[19] Kubik, K. (2012) 'Współczesne przedsiębiorstwa wobec wyzwań globalnej konkurencji', Zeszyty Naukowe Uniwersytetu Przyrodniczo-Humanistycznego $w$ Siedlcach, No. 92, pp. 33-49.

[20] Lisowska, R. (2015) 'Współpraca małych i średnich przedsiębiorstw w regionie - stymulatory i bariery', Prace Naukowe Uniwersytetu Ekonomicznego we Wrocławiu, No. 402, pp. 175-183.

[21] Małys, Ł. (2011) 'Współpraca z podmiotami zewnętrznymi a wyniki rynkowe małych i średnich przedsiębiorstw - analiza empiryczna', in Adamik, A. (ed.) Kształtowanie konkurencyjności i przewagi konkurencyjnej małych i średnich przedsiębiorstw, Warszawa: Wydawnictwo C.H. Beck.

[22] Mazur, J. (2011) 'Współpraca przedsiębiorstw w teorii i praktyce polskiej', Zeszyty Naukowe Szkoly Głównej Handlowej. Kolegium Gospodarki Światowej, No. 32, pp. 290-314.

[23] Olesiński, Z. (2010) Zarządzanie relacjami międzyorganizacyjnymi, Warszawa: Wyd. C.H. Beck.

[24] Polskie startupy. Raport 2015 (2015), Warszawa: Fundacja Startup Poland.

[25] Polskie startupy. Raport 2016 (2016), Warszawa: Fundacja Startup Poland.

[26] Porter, M.E. (2001) Porter o konkurencji, Warszawa: Polskie Wydawnictwo Ekonomiczne.

[27] Poznańska, K. (2010) 'Współpraca przedsiębiorstw w teorii i polityce gospodarczej', Zeszyty Naukowe Uniwersytetu Szczecińskiego, No. 579, Ekonomiczne Problemy Ustug, No. 47, pp. 167-175. 
[28] Ratajczak-Mrozek, M. (2011) 'Motywy współpracy małych i średnich przedsiębiorstw - wyniki badań', in Adamik, A. (ed.), Kształtowanie konkurencyjności i przewagi konkurencyjnej małych i średnich przedsiębiorstw, Warszawa: Wyd. C.H. Beck.

[29] Romanowska, M. (2001) 'Przedsiębiorstwo doskonałe w świetle współczesnych koncepcji zarządzania', in Godziszewski, B., Haffer, M. and Stankiewicz, M.J. (eds.) Przedsiębiorstwo na przełomie wieków, Toruń: Wydawnictwo Uniwersytetu Mikołaja Kopernika w Toruniu.

[30] Rundo, A. and Ziółkowska, M. (2013) Modele współpracy przedsiębiorstw, Warszawa: CeDeWu.

[31] Siuta-Tokarska, B. (2015) Podobieństwa i różnice w rozwoju przedsiębiorstw sektora MŚP z kapitałem krajowym i z udziałem kapitału zagranicznego w Polsce. Analiza i ocena wyników badań, Warszawa: Difin.

[32] Slatter, S. and Lovett, D. (2001) Restrukturyzacja firmy. Zarządzanie przedsiębiorstwem w sytuacjach kryzysowych, Warszawa: WIG-Press.

[33] Sulejewicz, A. (1997) Partnerstwo strategiczne: modelowanie współpracy przedsiębiorstw, Warszawa: Szkoła Główna Handlowa, Oficyna Wydawnicza.

[34] Strzyżewska, M. (2001) Współpraca między przedsiębiorstwami - odniesienie do polskiej praktyki, Warszawa: Szkoła Główna Handlowa, Oficyna Wydawnicza.

[35] The Oxford Handbook of Inter-Organizational Relations (2008) Cropper, S., Ebers, M., Huxham, Ch., and Ring, P.S. (eds.), Oxford: The Oxford University Press.

[36] Walas-Trębacz, J. (2004) 'Kooperacja zewnętrzna w zarządzaniu przedsiębiorstwem', Zeszyty Naukowe Małopolskiej Wyższej Szkoly Ekonomicznej $w$ Tarnowie, No. 5, pp. 143-157.

[37] Wojnicka, E. (2004) System innowacyjny Polski z perspektywy przedsiębiorstw, Gdańsk: IBnGR.

[38] Żmija K. (2011) 'Wybrane problemy obszarów wiejskich w Polsce', in Jaki, A., Kaczmarek, J. and Rojek, T. (eds.), Restrukturyzacja. Teoria i praktyka w obliczu nowych wyzwań, Kraków: Fundacja Uniwersytetu Ekonomicznego. 